UNITED STATES DEPARTMENT OF THE INTERIOR

GEOLOGICAL SURVEY

\title{
Analytical results and sample locality map of stream-sediment and heavy-mineral-concentrate samples from the \\ Eagle Mountains Wilderness Study Area (CDCA-334), \\ Riverside County, Cal ifornia
}

\author{
by \\ Gordon W. Day, Betty M. Adrian, Charles L. Whittington, \\ and Mary L. Tompkins
}

Open-File Report 85-372

This report is preliminary and has not been reviewed for conformity with U.S. Geological Survey editorial standards and stratigraphic nomenclature. Any use of trade names is for descriptive purposes only and does not imply endorsement by the USGS. 


\section{CONTENTS}

Page

Studies related to wilderness................................ 1

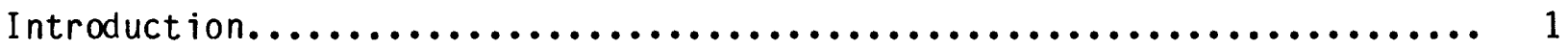

Methods of study ........................................ 1

Sample media........................................ 1

Sample collection....................................... 3

Stream-sediment samples............................... 3

Heavy-mineral-concentrate samples........................ 3

Sample preparation..................................... 3

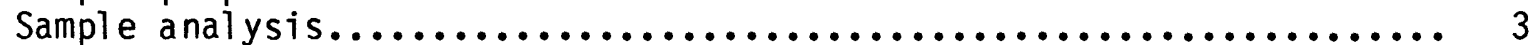

Rock Analys is Storage System (RASS) .......................... 4

Description of data tables.................................... 4

References cited......................................... 5

\section{ILLUSTRATIONS}

Figure 1. Index maps showing location of the Eagle Mountains Wilderness

Study Area, Riverside County, Cal ifornia....................

Plate 1. Map showing stream-sediment and heavy-mineral-concentrate sample sites.................................... in pocket

\section{TABLES}

Table 1. Limits of determination for spectrographic analysis of

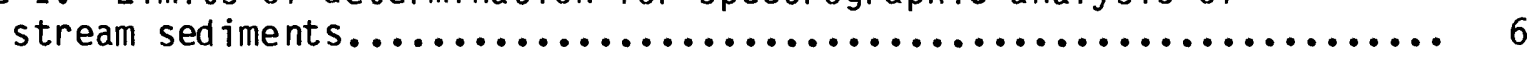

Table 2. Analyses of stream-sediment samples.................... 7

Table 3. Analyses of heavy-mineral-concentrate samples.............. 11 


\title{
STUDIES RELATED TO WILDERNESS
}

\author{
Bureau of Land Management Wilderness Study Areas
}

The Federal Land Policy and Management Act (Public Law 94-579, October $21,1976)$ requires the U.S. Geological Survey and the U.S. Bureau of Mines to conduct mineral surveys on certain areas to determine their mineral resource potential. Results must be made available to the public and be submitted to the President and the Congress. This report presents the results of a mineral survey of the Eagle Mountains Wilderness Study Area (CDCA-334), California Desert Conservation Area, Riverside County, California.

\section{INTRODUCTION}

In March 1982, the U.S. Geological Survey conducted a reconnaissance geochemical survey of the Eagle Mountains Wilderness Study Area, Riverside County, Cal ifornia.

The Eagle Mountains Wilderness Study Area lies abqut 150 miles (241 km) east of Los Angeles and comprises about $78 \mathrm{mi}^{2}\left(202 \mathrm{~km}^{2}\right)$ in the southeastern and east-central parts of the Eagle Mountains (see fig. 1). The western boundary of the area abuts Joshua Tree National Monument, the northern boundary skirts the Eagle Mountains mining district, and parts of the southern and eastern boundaries follow the Colorado River Aqueduct. The southern boundary 1 ies about 2 to 3 miles north of Interstate Highway 10, and parts of the northern boundary lie less than a mile south of Black Eagle mine road. Access to the interior of the area is provided mainly by jeep trails in Big Wash and in an unnamed north-draining wash in the western part.

Much of the study area is ruggedly mountainous, but spacious areas of subdued relief exist in parts of the interior. Elevations vary from about 1,400 feet $(427 \mathrm{~m})$ in Big Wash at the eastern boundary to 3,994 feet $(1,217 \mathrm{~m})$ on a peak about one mile east of the western boundary. The climate is arid, and vegetation is quite sparse.

Most of the bedrock in the study area consists of metaigneous and metasedimentary rocks of Precambrian and(or) Paleozoic age and batholithic rocks of Mesozoic age. Cutting the metamorphic and batholithic rocks are numerous felsic to mafic dikes of Mesozoic and (or) Cenozoic age. Extensive alluvial deposits are present in parts of the area. The geology is described by Powell (1981) and summarized in Powell and others (1984).

\section{METHODS OF STUDY}

\section{Sample Media}

Analyses of the stream-sediment samples represent the chemistry of the rock material eroded from the drainage basin upstream from each sample site. Such information is useful in identifying those basins which contain concentrations of elements that may be related to mineral deposits. Heavymineral-concentrate samples provide information about the chemistry of a 1 imited number of minerals in rock material eroded from the drainage basin upstream from each sample site. The selective concentration of minerals, many of which may be ore-related, permits determination of some elements that are not easily detected in stream-sediment samples. 


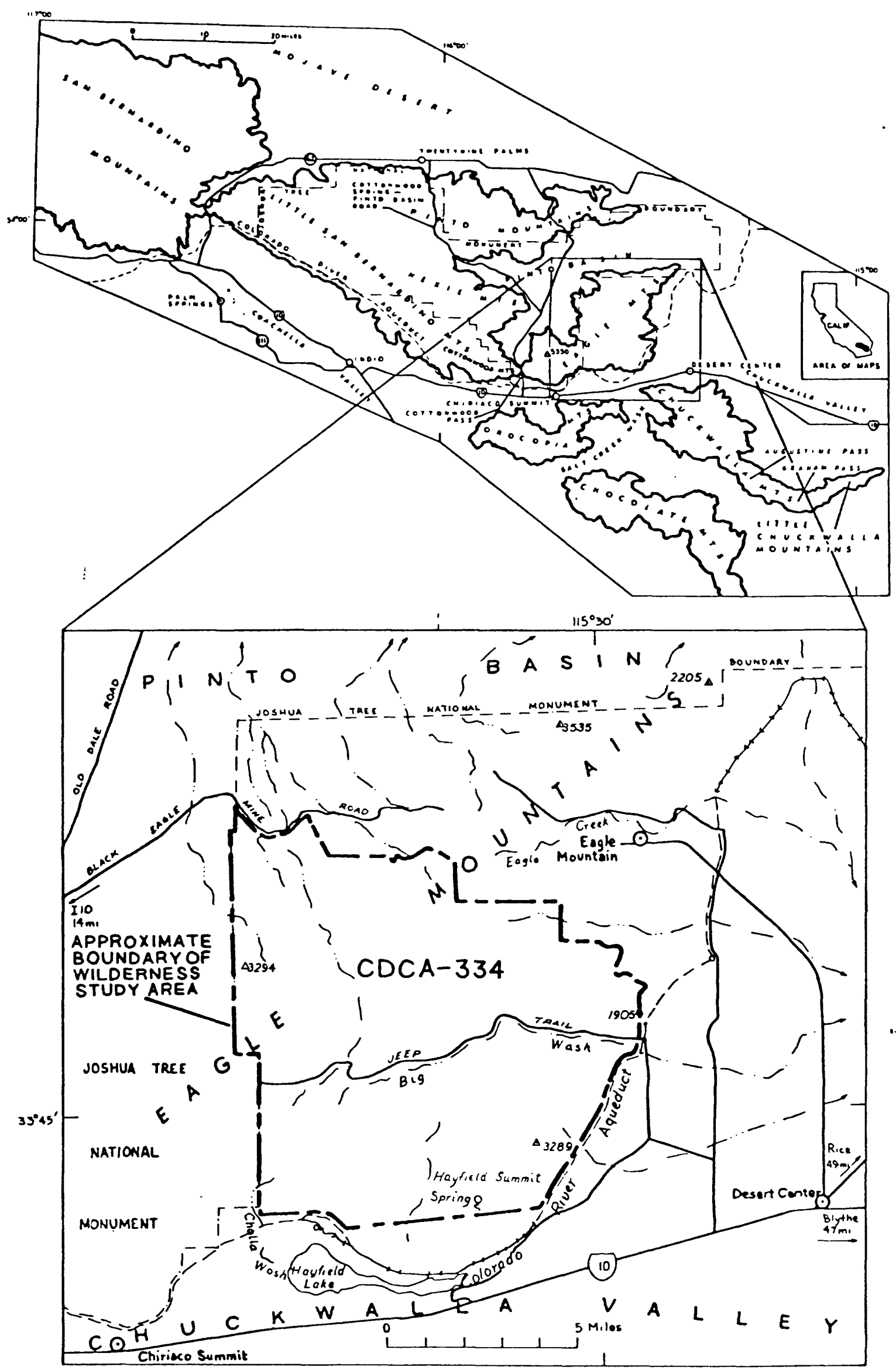

Figure 1.--Index maps showing location of the Eagle Mountains Wilderness Study Area (CDCA-334), California Desert Conservation Area, Riverside County, Cal ifornia. 


\section{Sample Collection}

Samples were collected at 78 sites (plate 1). Sufficient material was collected at each site to subsequently prepare both a sieved sediment sample and a heavy-mineral-concentrate sample. Sampling density was about one sample per $1 \mathrm{mi}^{2}$ for the stream sediments and heavy-mineral concentrates.

\section{Stream-sediment samples}

The stream-sediment samples consisted of alluvium collected from dry stream beds. The sampled material at each site was composited from several localities in an area 2 to 15 meters wide that extended across what appeared to be the most recently active stream channel.

\section{Heavy-mi neral-concentrate samples}

Heavy-mineral-concentrate samples were collected from the same alluvium as the stream-sediment samples. Bulk samples that did not contain enough coarse material to be screened were panned until most of the quartz, feldspar, organic matter, and clay-sized material were removed.

\section{Sample Preparation}

The stream-sediment samples were air dried, then sieved using 80-mesh $(0.17-\mathrm{mm})$ stainless steel sieves. The portion of the sediment passing through the sieve was saved for analysis.

After air drying, bromoform (specific gravity 2.8) was used to remove the remaining quartz and feldspar from the heavy-mineral-concentrate samples that had been panned in the field. The resultant heavy-mineral sample was separated into three fractions using a large electromanet (in this case a modified Frantz Isodynamic Separator). The most magnetic material, primarily magnetite, was not analyzed. The second fraction, largely ferromagnesian silicates and iron oxides, was saved for analysis/archival storage. The third fraction (the least magnetic material including the nonmagnetic ore minerals, zircon, sphene, etc.) was split using a Jones splitter. One spl it was handground for spectrographic analysis; the other spl it was saved for mineral ogical analysis. These magnetic separates are the same separates that would be produced by using a Frantz Isodynamic Separator set at a slope of $15^{\circ}$ and a tilt of $10^{\circ}$ with a current of 0.1 ampere to remove the magnetite and ilmenite, and a current of 1.0 ampere to split the remainder of the sample into paramagnetic and nonmagnetic fractions.

\section{Sample Analysis}

The stream-sediment and heavy-mineral-concentrate samples were analyzed for 31 elements using a semiquantitative, direct-current arc emission spectrographic method (Grimes and Marranzino, 1968). The elements analyzed and their lower limits of determination are 1isted in table 1. Spectrographic results were obtained by visual comparison of spectra derived from the sample against spectra obtained from standards made from pure oxides and carbonates. Standard concentrations are geometrically spaced over any given order of magnitude of concentration as follows: $100,50,20,10$, and so forth. Samples whose concentrations are estimated to fall between those 
values are assigned values of $70,30,15,7$, and so forth. The precision of the analytical method is approximately plus or minus one reporting interval at the 83 percent confidence level and plus or minus two reporting intervals at the 96 percent confidence level (Motooka and Grimes, 1976). Values determined for the major elements ( $\mathrm{Fe}, \mathrm{Mg}, \mathrm{Ca}$, and $\mathrm{Ti}$ ) are given in weight percent; all others are given in parts per million (micrograms/gram). Analytical data for samples from the Eagle Mountains Wilderness Study Area are listed in tables 2 and 3.

\section{ROCK ANALYSIS STORAGE SYSTEM}

Upon completion of all analytical work, the analytical results were entered into a computer-based file called Rock Analysis Storage System (RASS). This data base contains both descriptive geological information and analytical data. Any or all of this information may be retrieved and converted to a binary form (STATPAC) for computerized statistical analysis or publication (VanTrump and Miesch, 1976).

\section{DESCRIPTION OF DATA TABLES}

Tables 2 and 3 list the analyses for the samples of stream sediment and heavy-mineral concentrate, respectively. For the two tables, the data are arranged so that column 1 contains the USGS-assigned sample numbers. These numbers correspond to the numbers shown on the site location maps (plate 1). Columns in which the element headings show the letter "s" below the element symbol are emission spectrographic analyses. A letter " $N$ " in the tables indicates that a given element was looked for but not detected at the lower limit of determination shown for that element in table 1. If an element was observed but was below the lowest reporting value, a "less than" symbol $(<)$ was entered in the tables in front of the lower limit of determination. If an element was observed but was above the highest reporting value, a "greater than" symbol ( $>$ ) was entered in the tables in front of the upper limit of determination. Because of the formatting used in the computer program that produced tables 2 and 3 , some of the elements 1 isted in these tables ( Fe, $\mathrm{Mg}$, $\mathrm{Ca}$, and $\mathrm{Ti}$ ) carry one or more nonsignificant digits to the right of the significant digits. The analysts did not determine these elements to the accuracy suggested by the extra zeros.

The spectrographic determinations for $\mathrm{Ag}, \mathrm{As}, \mathrm{Au}, \mathrm{Bi}, \mathrm{Cd}, \mathrm{Mo}, \mathrm{Sb}$, and $\mathrm{W}$ in stream-sediment samples, and for $\mathrm{As}, \mathrm{Au}, \mathrm{Cd}, \mathrm{Sb}, \mathrm{Sc}, \mathrm{Zn}$, and $\mathrm{Zr}$ in heavymineral-concentrate samples were all below the lower limits of determinations shown in table 1; consequently, the columns for these elements have been deleted from tables 2 and 3, respectively. There are only three streamsediment samples (EM001, EM052, and EM077) in which $\mathrm{Zn}$ was observed, but in each the $Z n$ was below the lowest reporting value of $200 \mathrm{ppm}$. These samples are shown in the data table with an asterisk before the sample number and a footnote stating that $\mathrm{Zn}$ was observed at $<200 \mathrm{ppm}$. 


\section{REFERENCES CITED}

Grimes, D. J., and Marranzino, A. P., 1968, Direct-current arc and alternating-current spark emission spectrographic field methods for the semiquantitative analysis of geologic materials: U.S. Geological Survey Circular 591, 6 p.

Motooka, J. M., and Grimes, D. J., 1976, Analytical precision of one-sixth order semiquantitative spectrographic analyses: U.S. Geological Survey Circular 738, 25 p.

Powel 1, R. E., 1981, Geology of the crystalline basement complex, Eastern Transverse Ranges, southern California--Constraints on regional tectonic interpretation: Cal ifornia Institute of Technology, Pasadena, Ph.D. thesis, $441 \mathrm{p}$.

Powel 1, R. E., Whittington, C. L., Granch, V. J. S., and McColly, R. A., 1984 , Mineral resource potential map of the Eagle Mountains Wilderness Study Area (CDCA-334), Riverside County, Cal ifornia: U.S. Geological Survey Open-File Report 84-631, scale 1:62,500.

VanTrump, George, Jr., and Miesch, A. T., 1976, The U.S. Geological Survey RASS-STATPAC system for management and statistical reduction of geochemical data: Computers and Geosciences, v. 3, p. 475-488. 
TABLE 1.--Limits of determination for the spectrographic analysis of stream sediments, based on a 10-mg sample

[The spectrographic limits of determination for heavy-mineral-concentrate samples are two reporting units higher than the limits given for rocks and stream sediments]

Elements Lower determination limit Upper determination limit

Percent

\begin{tabular}{lcc}
\hline Iron (Fe) & 0.05 & 20 \\
Magnesium (Mg) & .02 & 10 \\
Calcium ( Ca) & .05 & 20 \\
Titanium (Ti) & .002 & 1 \\
\hline
\end{tabular}

Parts per million

\begin{tabular}{lrr}
\hline & & \\
Manganese (Mn) & 10 & 5,000 \\
Silver (Ag) & 0.5 & 5,000 \\
Arsenic (As) & 200 & 10,000 \\
Gold (Au) & 10 & 500 \\
Boron (B) & 10 & 2,000 \\
Barium (Ba) & 20 & 5,000 \\
Beryl lium (Be) & 1 & 1,000 \\
Bismuth (Bi) & 10 & 1,000 \\
Cadmium (Cd) & 20 & 500 \\
Cobalt (Co) & 5 & 2,000 \\
Chromium (Cr) & 10 & 5,000 \\
Copper (Cu) & 5 & 20,000 \\
Lanthanum (La) & 20 & 1,000 \\
Molybdenum (Mo) & 5 & 2,000 \\
Niobium (Nb) & 20 & 2,000 \\
Nickel (Ni) & 5 & 5,000 \\
Lead (Pb) & 10 & 20,000 \\
Antimony (Sb) & 100 & 10,000 \\
Scandium (Sc) & 5 & 100 \\
Tin (Sn) & 10 & 1,000 \\
Strontium (Sr) & 100 & 5,000 \\
Vanadium (V) & 10 & 10,000 \\
Tungsten (W) & 50 & 10,000 \\
Yttrium (Y) & 10 & 2,000 \\
Zinc (Zn) & 200 & 10,000 \\
Zirconium ( $r r) ~$ & 1,000 \\
Thorium (Th) & 10 & 2,000 \\
& 100 & \\
\hline
\end{tabular}




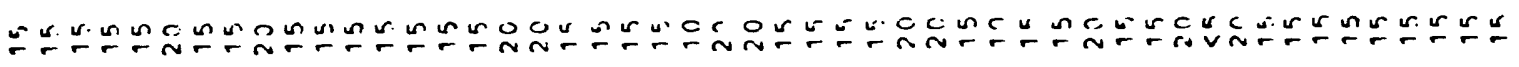

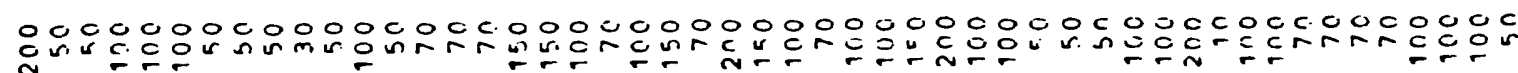

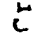

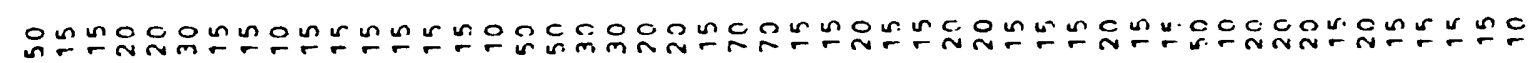
$\grave{3}^{\prime \prime}$

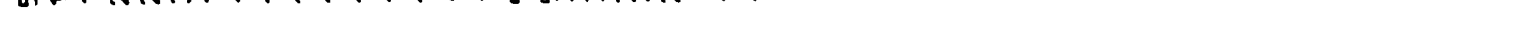
点n

00000000000000000000000000000000000000000000000000

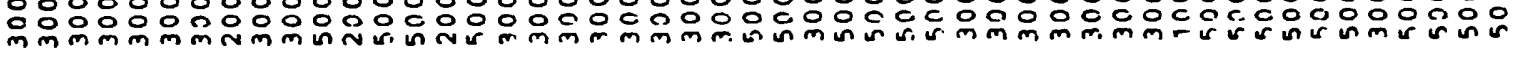

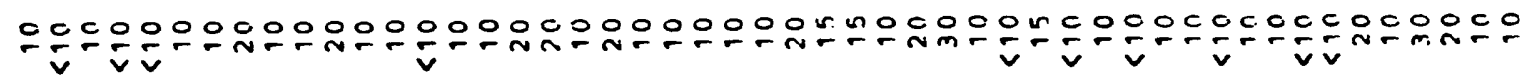

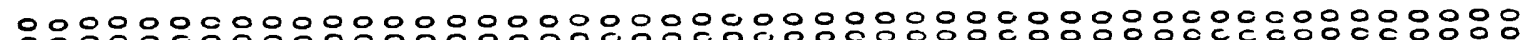

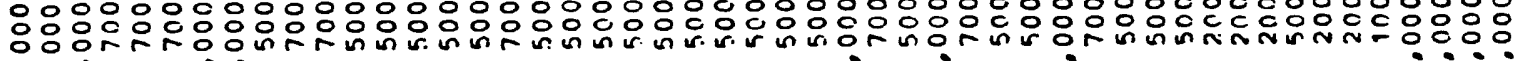
$i$ is 空 $\because \because \quad \because$

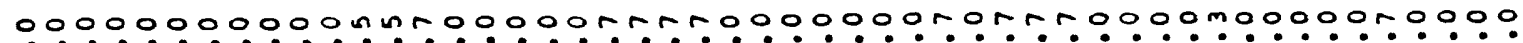

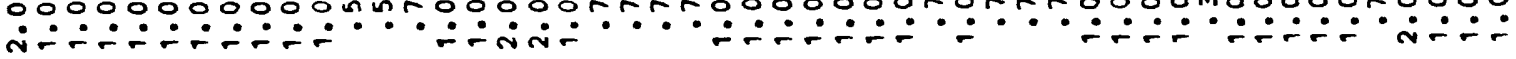

000000000 000000000000090000000000000000\%0000000000

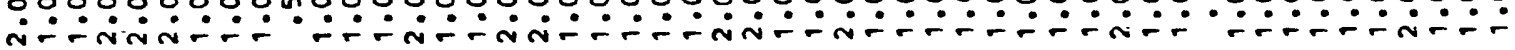

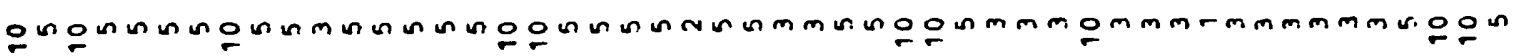
is

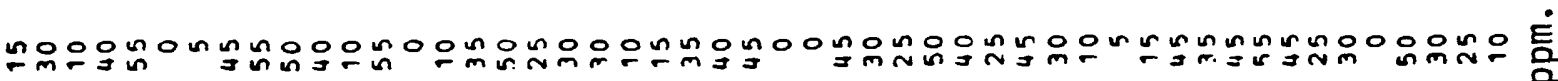

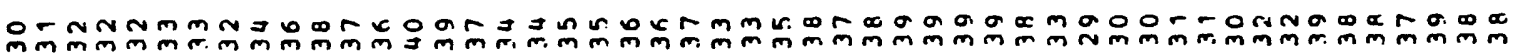

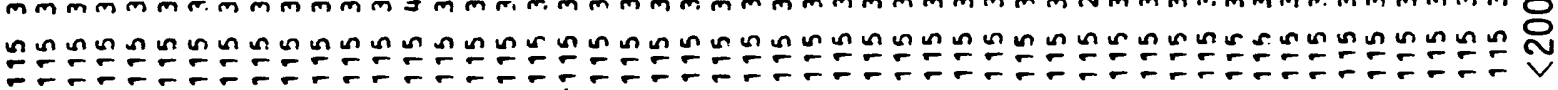

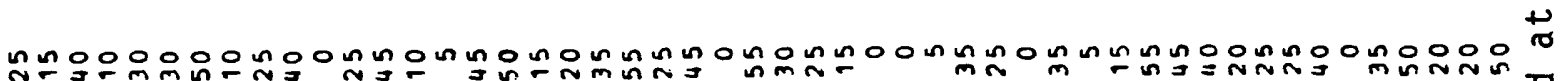

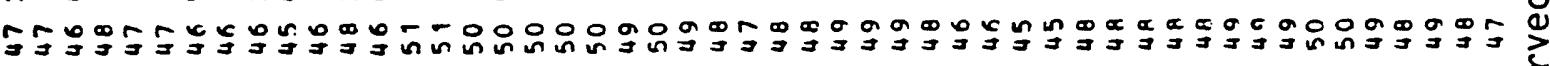
mmmmmm 


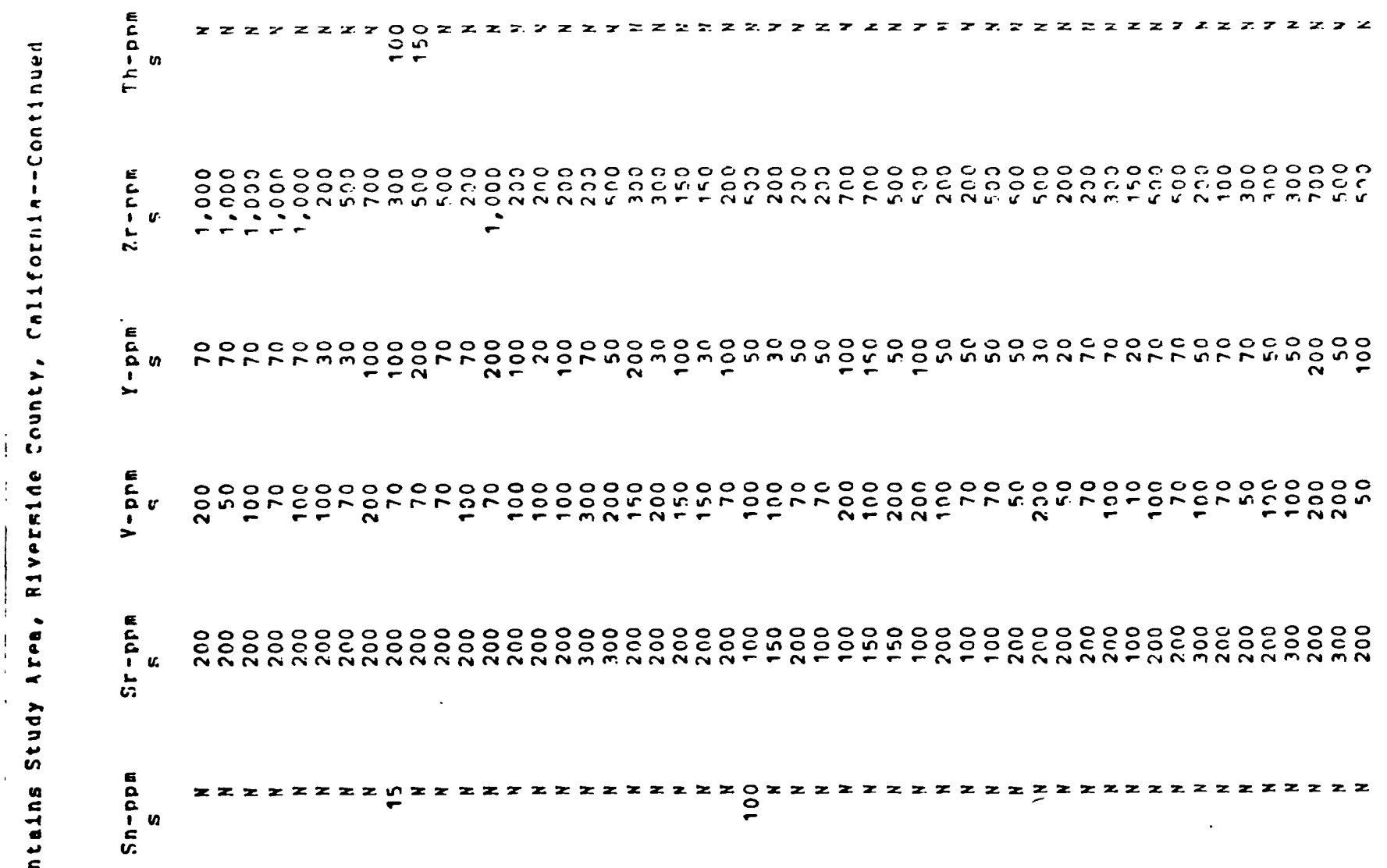

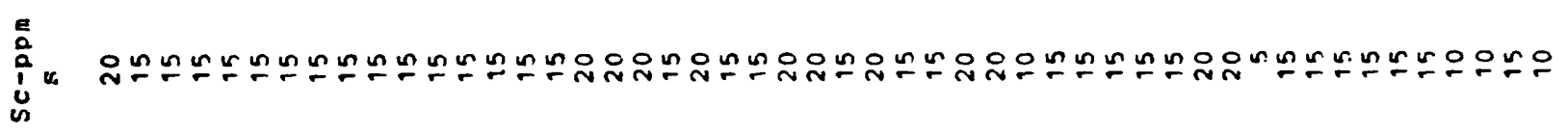

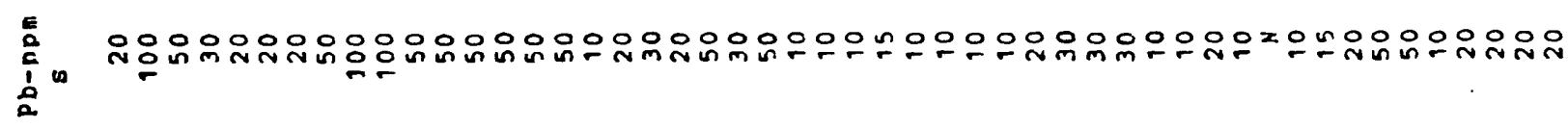

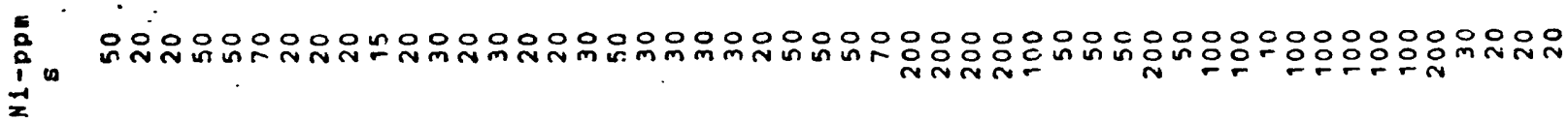
望 E

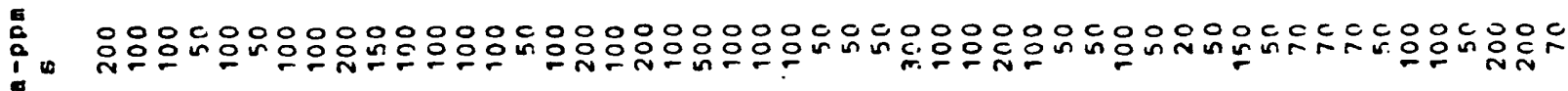
$\rightarrow$ 


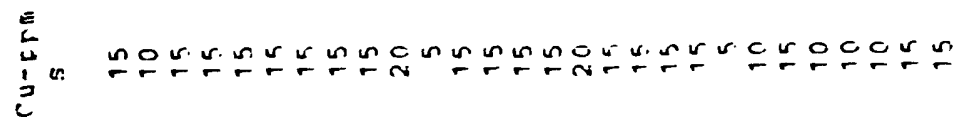

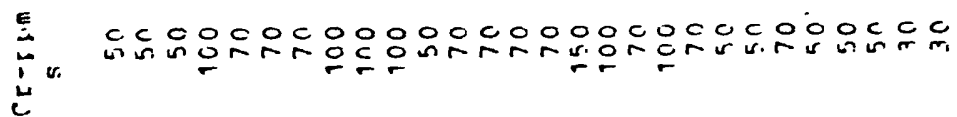

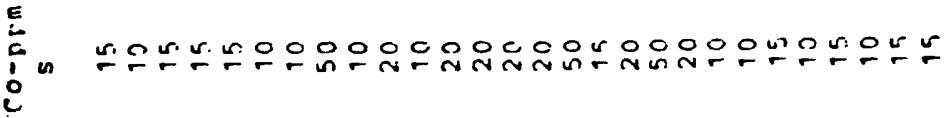

E
$\vdots$
$\vdots$
$\vdots$
$\vdots$

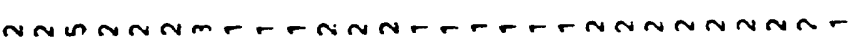

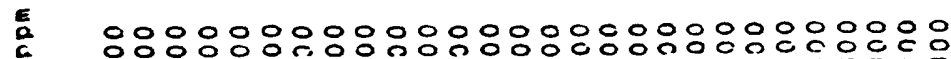

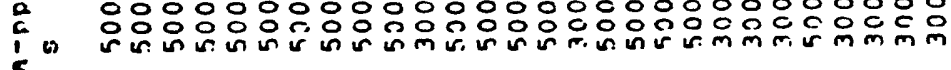

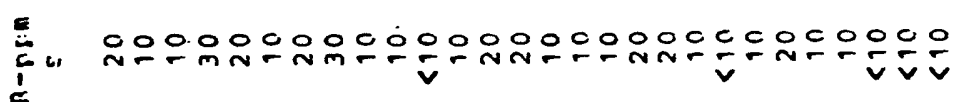

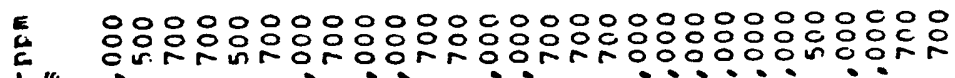
i. " a nin

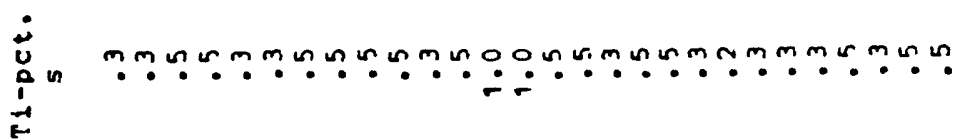

Un
ín
ú

$\dot{0}_{0}^{0}$

范

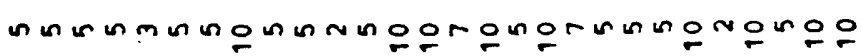
\&

엉에

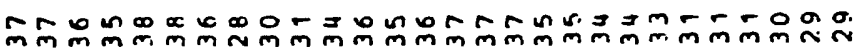

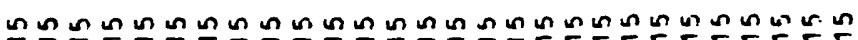

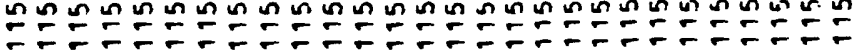

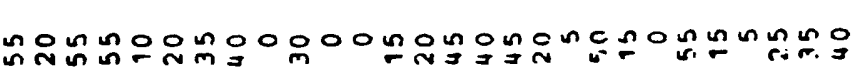
ริ

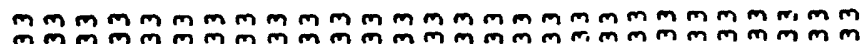

言

尺 


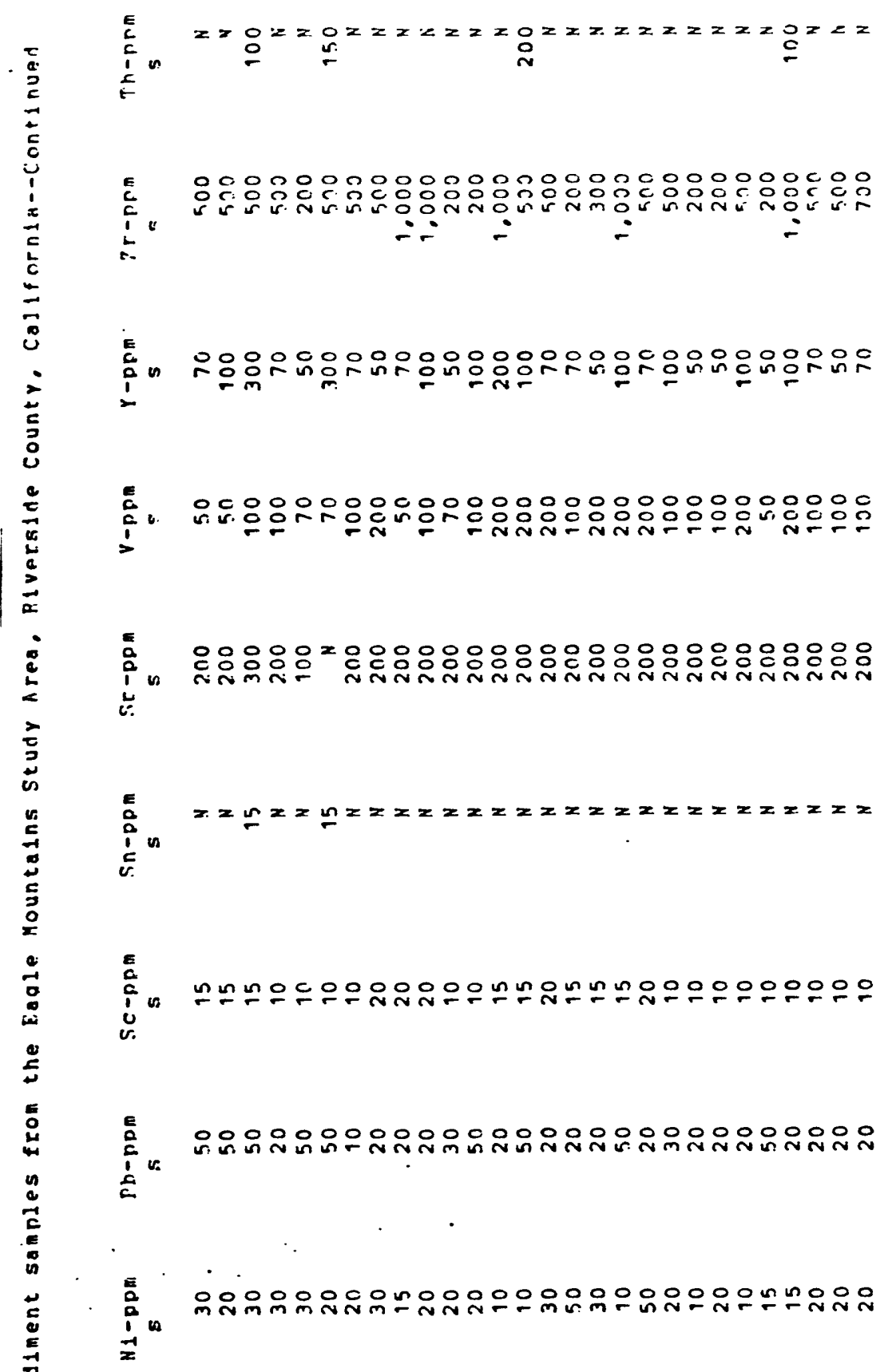

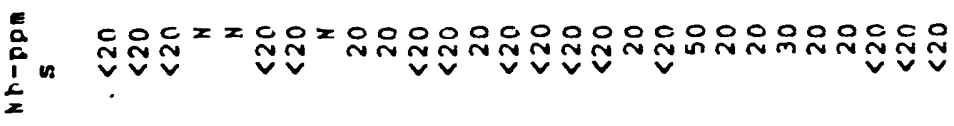
E 
产

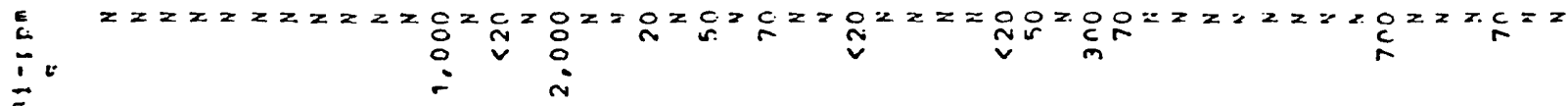
$\vec{E}$

ind

$\stackrel{a}{a}$

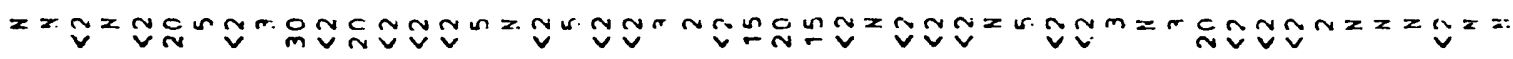

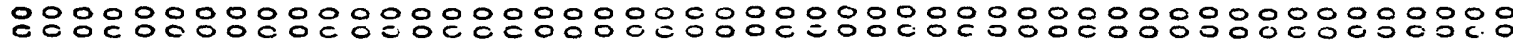
cinonion $i n$ is in i $\because$ $\therefore \sin$

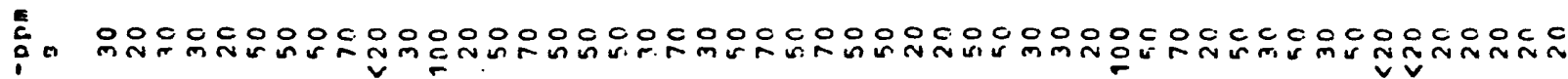
$\underline{1}$

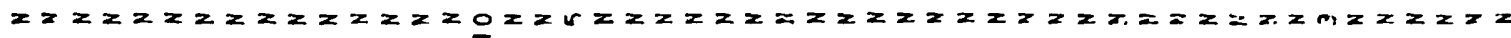

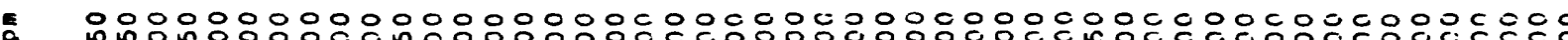
$i_{0}^{\infty}$ c

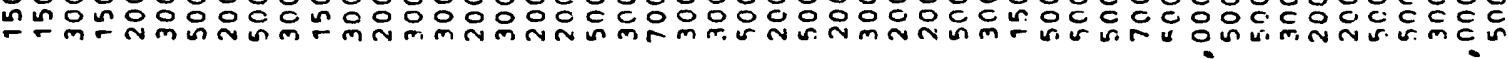

0 no $0000 n 000000000000000000000000000000000000000000$ u in $\vec{E}$

$\stackrel{\dot{u}}{c}$

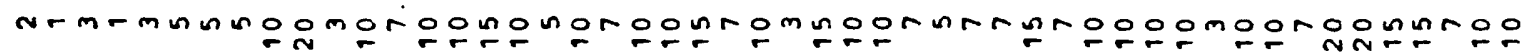
i

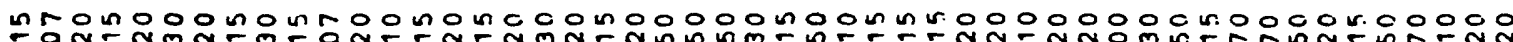

苍 :

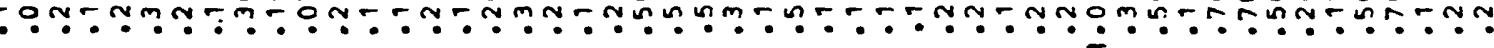

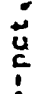

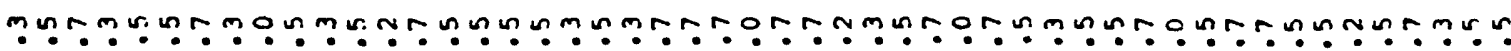
a.

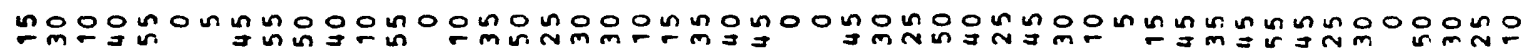

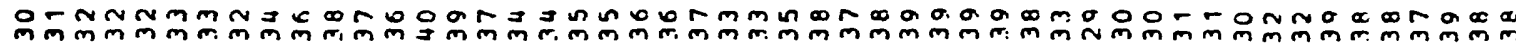
ำ

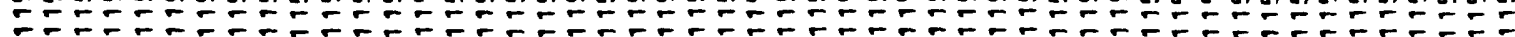

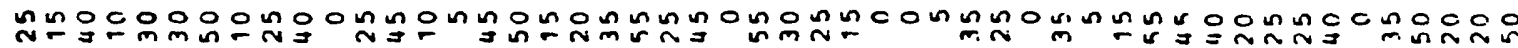

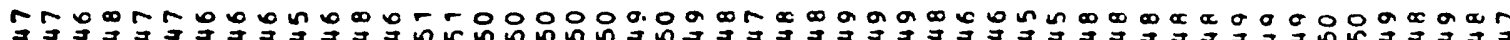

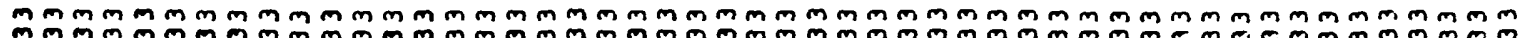

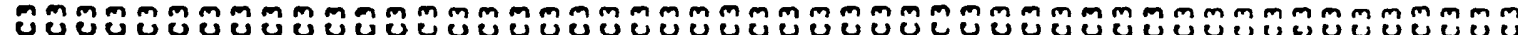

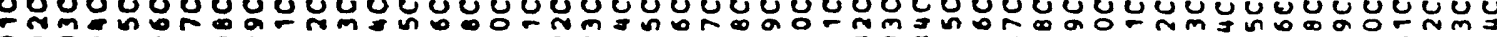

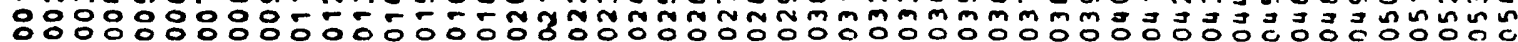

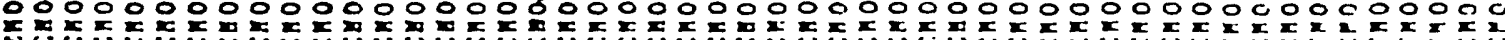




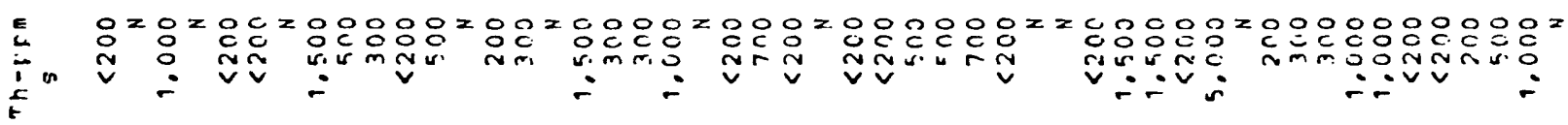

- 00000000000000000000000000000000000000000000000000

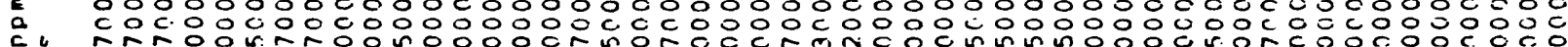

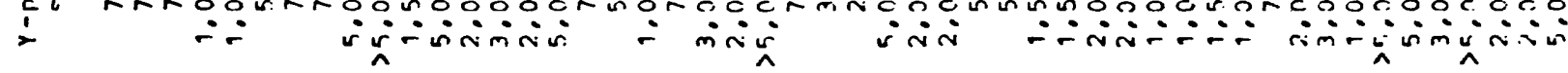

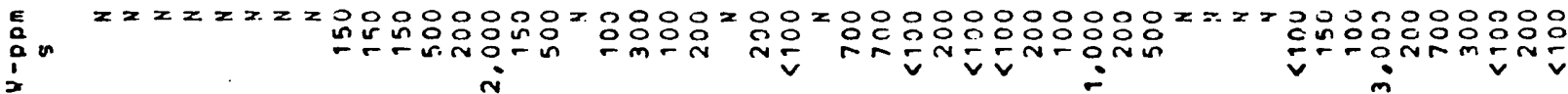

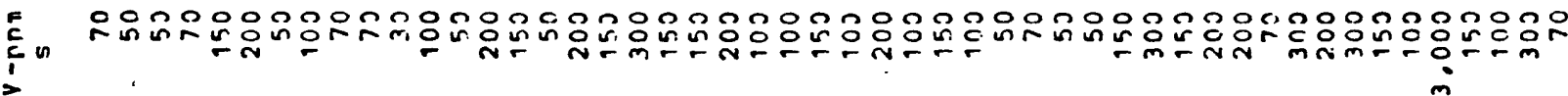

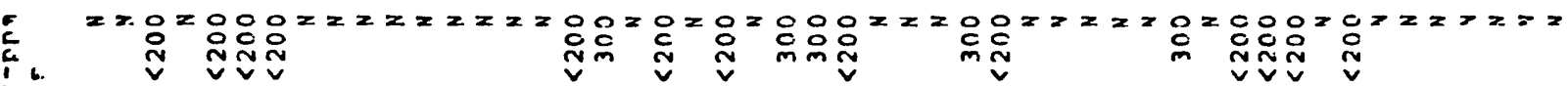
i.

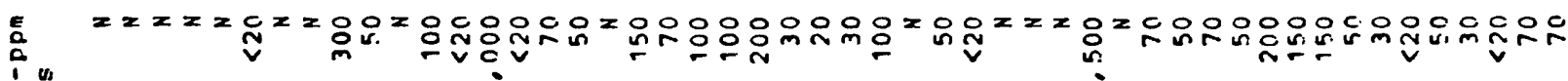
$\stackrel{c}{c}^{u}$ i

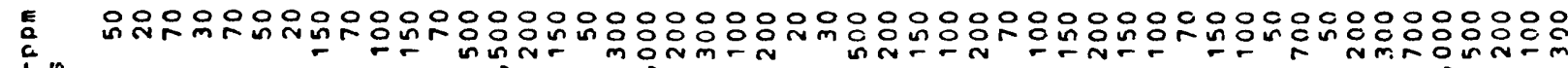

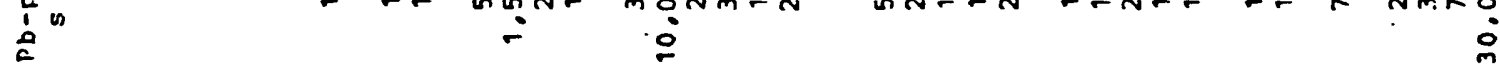

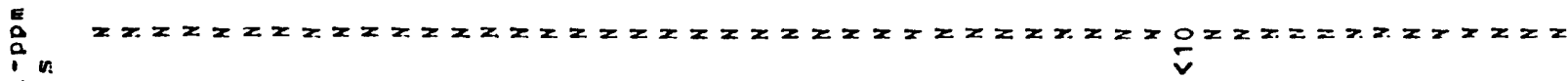
$=$

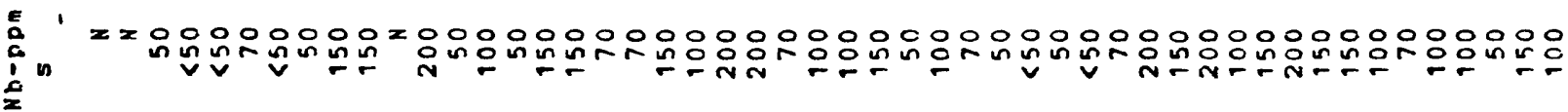

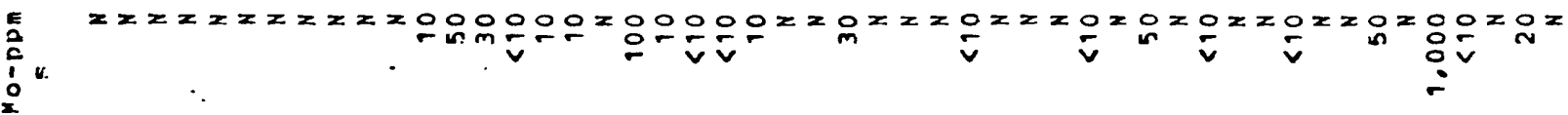

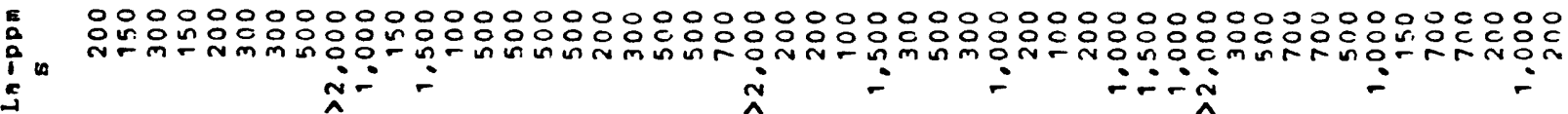

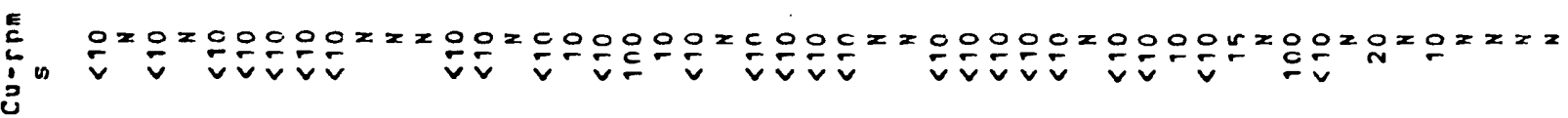

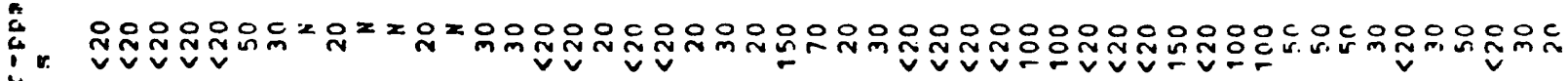
in

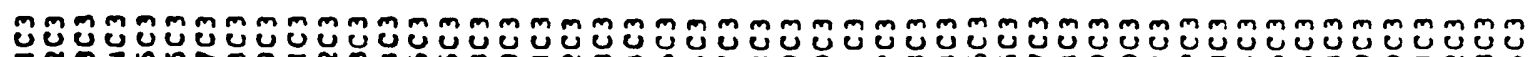
N

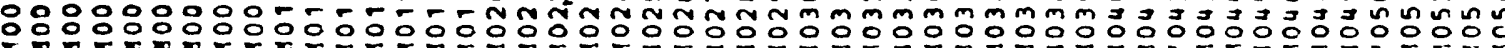

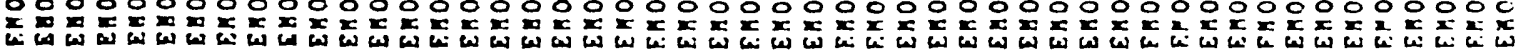




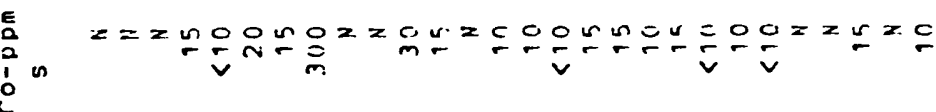

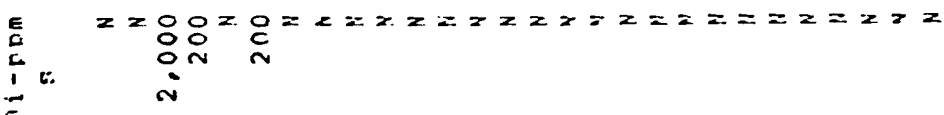

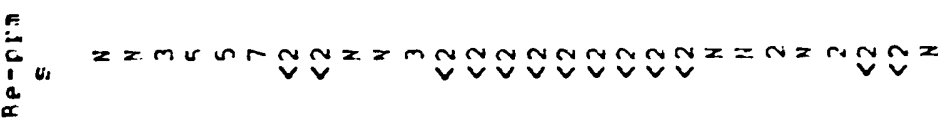

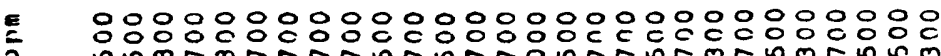
in 幺́m

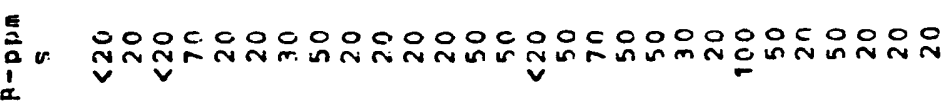

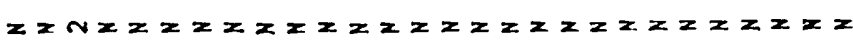
in

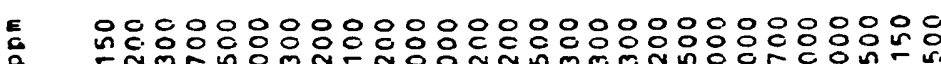

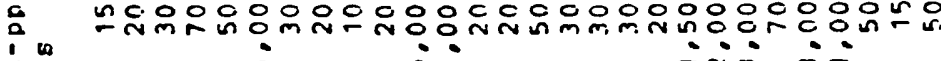
E n n नnim in

- oon $00000-0000000000000000000$

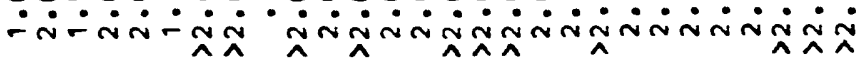
3 :

is 䓀

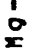

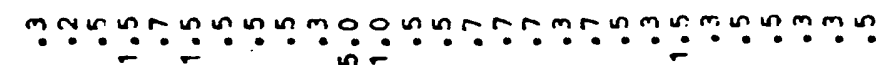
i

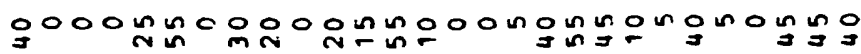

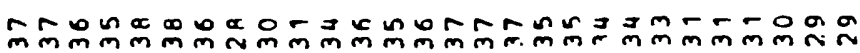

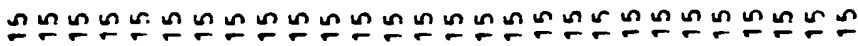

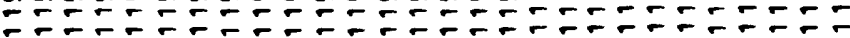

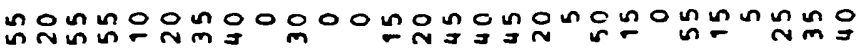

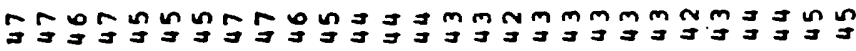

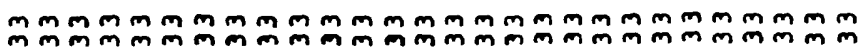

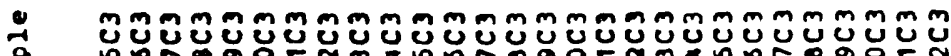
กั0r

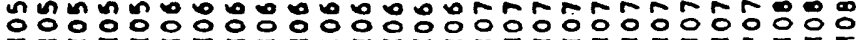

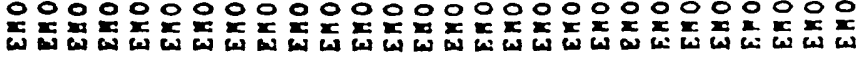




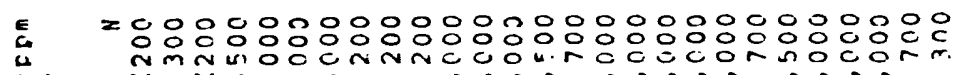

ind

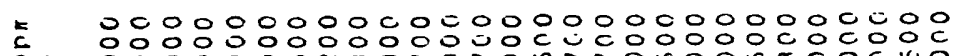

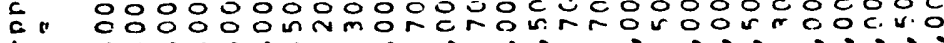

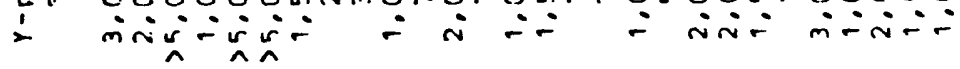

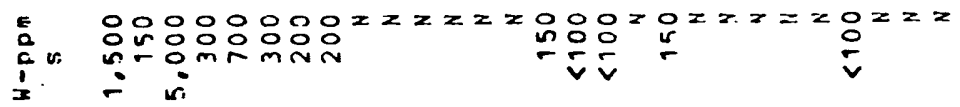

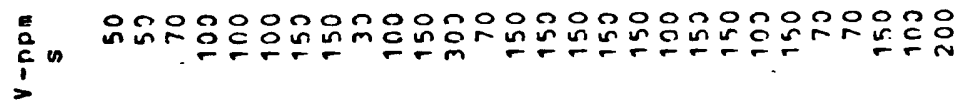

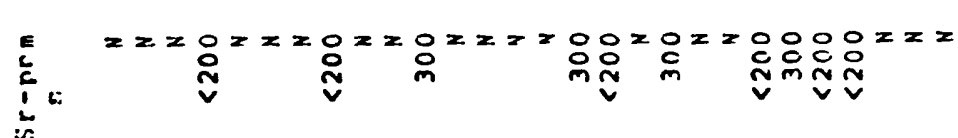

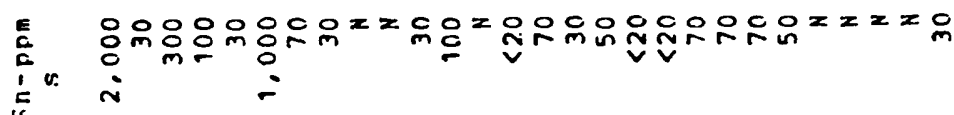

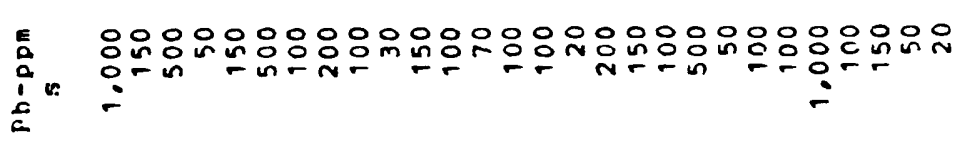

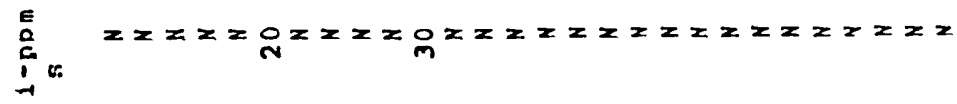

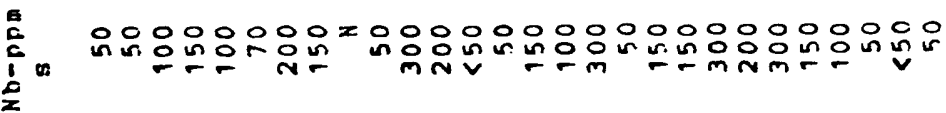

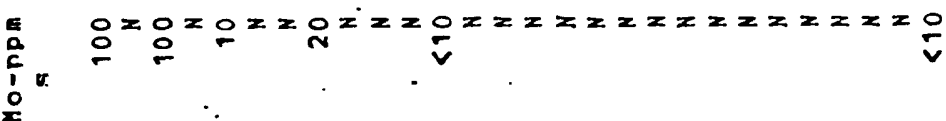

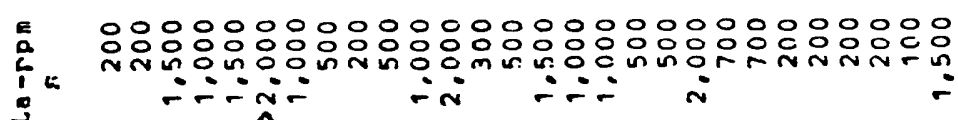

E
U [ú 